This is a self-archived - parallel published version of this article in the publication archive of the University of Vaasa. It might differ from the original.

\title{
Partnership and Capacity Building of Local Governance
}

Author(s): Asaduzzaman, Mohammed; Virtanen, Petri

Title: $\quad$ Partnership and Capacity Building of Local Governance

Year: $\quad 2020$

Version: Accepted manuscript

Copyright (C) Springer Nature Switzerland AG 2020. This is a post-peer-review, pre-copyedit version of an article published in Partnerships for the Goals. Encyclopedia of the UN Sustainable Development Goals. The final authenticated version is available online at: http://dx.doi.org/10.1007/978-3-319-71067-9_21-1.

\section{Please cite the original version:}

Asaduzzaman, M. \& Virtanen, P. (2020). Partnership and Capacity Building of Local Governance. In: Leal Filho, W., Azul, A. M., Brandli, L., Salvia, A.L. \& Wall, T. (Eds.) Partnerships for the Goals.

Encyclopedia of the UN Sustainable Development Goals, 1-20. Cham: Springer. https://doi.org/10.1007/978-3-319-71067-9_21-1 


\section{Partnership and Capacity Building of Local Governance}

Mohammed Asaduzzaman, $\mathrm{PhD}$

Professor, Department of Public Administration

Islamic University, Kushtia-7003, Bangladesh

E-mail: asaduzzaman.mohammed@gmail.com

And

Petri Virtanen, $\mathrm{PhD}$

CEO, ITLA The Finnish Children's Foundation and

Professor of Administrative Sciences

University of Vaasa (Social and Health Management)

E-mail: petri.virtanen@itla.fi

Synonyms: Network Governance, Participatory Governance, Collaborative Governance, Integrative Governance, Cooperative Governance and Co-creation Governance

\section{Definition}

Partnership is about sharing of power, responsibility and achievements. According to the World Bank Public Private Partnership (PPP) promoting group, "partnership refer to informal and shortterm engagements of non-governmental organizations, the private sector and/or government agencies that join forces for a shared objective; to more formal, but still short-term private sector engagements for the provision of specific services, for example, annual outsourcing arrangements for janitorial services for a school or operations of the school cafeteria; to more complex contractual arrangements, such as build, operate, transfer regimes, where the private sector takes on considerable risk and remains engaged long term; or to full privatizations" (World Bank Group 2014, 29).

\section{Introduction}

It has been widely recognized that the traditional public administration has not been able to meet the challenges of $21^{\text {st }}$ century of developing world, though it has played historic role in the economic development throughout the world. Since the mid-1970s traditional public administration has come under severe criticisms and rejected because of (i) it was too large, consuming too many scarce resources; (ii) it was involved in too many activities, whereas alternative means of provision existed for many of these; (iii) growing inflation, excessive costs 
and excessive bureaucracies resulted from state intervention; and (iv) inefficient, costly, rigid, corrupt, unaccountable, and unsuitable to an age seeking more dynamic models of social and economic development (Minogue, 1998; Hughes, 1998: Sarker 2006, pp. 181-182). As a result, public administration has shifted into a new paradigm but in different names i.e. partnership, public-private partnership, networking etc. Working in partnership across government departments and their agencies and with the community, voluntary and business sectors and trade unions is central to government policies for tackling complex problems of $21^{\text {st }}$ century ranging from corruption, poverty to climate change (e.g. Boydell 2007).

Partnership has thus evolved concerning the governance underlining the new institutional arrangements both in the developed and developing countries. This new formulation is primarily due to four fundamental factors such as economic globalization, the remarkable breakthrough in information technology, the changing scenario of the national and international politics across the world, the collapse of the pre-existing political order and the rise of the Non-Profit Institutions (Olowu 2003; Samaratunge et al 2008; Peters 2001). According to McQuaid (2000, p.11), partnership has gained great concern for some pragmatic and ideological factors such as: (i) a belief in the overall advantages of a partnership approach; (ii) the move towards enabling local government (where publicly funded services are implemented by private or not for-profit bodies rather than by the public sector); (iii) a recognition that any one local actor often does not have all the competencies or resources to deal with the inter-connected issues raised in many policy areas; and (iv) the genuine participation of the local community.

The role of local institutions remains significant for the realization of people-centered development in developing nations despite the policy shift towards privatization, deregulation and globalization. In fact, with the diminishing role of the state in programs such as poverty eradication, employment generation, public health, and basic education, the role of local institutions in addressing the needs of local communities has increased. However, due to the politicization and bureaucratization of local institutions of developing countries and the imposition of various programs on them by the central government, these institutions can hardly be responsive to the local needs. (Sarker and Zafarullah, 2019; Brinkerhoff, 2002; Levy, 2015; Blair, 2000; Burde, 2004; Haque, 2003, \& 1996; Cornwall, 2003).

On the other hand, a number of studies have claimed that the development activities run by the NGOs and the civil societies are flexible, innovative, participatory, cost effective, and 
directed at the poor. An appraisal team of the World Bank found that the NGOs and civil societies are more effective than the public institutions in reaching out to the rural poor. It has been found that local people trust more on NGOs and civil society organizations rather than local public institutions (Hodge 2014, Birner \& Wittmer, 2009; 2016; Haque, 2004). Developed world have also progressively developed their private sector capacity and such companies are considered as not only important part of wealth generating business sector, but also capable and reliable government partners for potentially supplying infrastructure on behalf of the government.

This paperintends to highlight the insights of partnership as a tool in building capacity of local governance with special reference to developing countries. This paper assumes that until and unless all stakeholders (public institutions, civil society, NGOs, civil servants and private sectors) are brought together within a partnership framework, the capacity of local governance will not enhance and thus the commitment of sustainable development will probably never find its place.

The chapter takes a journey. Firstly, it sets sail by better understanding of key concepts such partnership governance and local governance. Secondly, it traces the advantages of partnership in building capacity of local governance and also risk and challenges of partnership building. Thirdly, it concludes with summary and further research agenda. Overall, this paper grounds on interpretation and re-interpretation of secondary research literature.

\section{Theoretical understanding of key concepts}

\section{Partnership as a development doctrine}

'Partnership building' is a very old concept, date back two and half thousand years to the Persian Achaemenid Empire though it has been considered as a new alternative in provision of service delivery at the beginning of 1980s (Farazmand 1998; Kouwenhoven 1993). As an instrument of NPM, it gained importance at the early of 1990s. Since 2015, partnership became an essential mechanism in ensuring and achieving sustainable development.

As a result, 'partnership' has, as a concept, of paramount importance worldwide, from development to business, from charity organizations to profit-making companies and even within family business (Asaduzzaman et.al. 2016). The international institutions such as the World Bank, the UNDP, the African Union and the European Union have also been enthusiastically 
promoting the issue of partnership especially since 2015 to ensure good governance and sustainable development in the developing world.

Today, partnership can be defined as a collaborative engagement of three key sectors of the state such as business, government and civil society (Austin 2000; Gray 1989; Stone 2000, Young 1999). These sectors jointly address critical issues of the society such as economic development, education, health care, poverty alleviation, community capacity building, disaster management, and environmental sustainability (Selsky \& Parker 2005).

Moreover, Farazmand (2004, pp. 94-97; 1999) discusses the contents of partnership broadly through five different approaches which have independent principles, methods and frameworks. They are: (i) autonomous approach; (ii) independent approach; (iii) globalization convergence approach; (iv) hybrid approach; and (v) elite approach.

The autonomous approach is built on the proposition of independence exercised by all actors or stakeholders equally. It includes (a) state initiation with NGOs, citizens, and private sector; (b) initiation through proposals and policy idea formulations with government by all other partners; and (c) third-party initiation to pull governmental and other parties into partnership building at local and national levels.

The interdependence approach is very common among nation-states at regional and global levels. This type of partnership is built on the belief that all parties are living in an interdependent world in which no one is self-sufficient or has the capability and resources to deal with problems of an interdependent world.

The globalization-convergence approach is based on the forces of globalizationfinance, production, marketing, state and political integration, and cultural, economic, and policy convergence. This is a potentially repressive partnership approach, because it tends to turn almost all less-developed and other industrialized nations with weak military power into forced coalitions, rather than build free partnerships, for the dictation of unilateral policy choices to the rest of the world.

The hybrid approach is a combination of the autonomous, interdependence and globalization-convergence approach. At the outset, hybrid approach is very effective for developed nations. However, local governance partnerships may also have a negative effect for less-developed countries when faced with forces of globalization: in this case, their strategic choices simply become reactive. 
The elite approach is very common feature of contemporary modern governance partnership building, with the idea that elites-economic-corporate and political elites-govern the policy arena of governance in everywhere. According to this approach elite-dominated governance positions can be based on assumptions that non-elite masses are not capable enough to run governance, so reserving such rights and privileges for themselves. Elites are by nature intended to exclude non-elites purely for their own interests.

Partnership as a strategy of sustainable development first highlighted in the Rio Declaration 1992 with the meaning that involvement of major stakeholders in decision making and policy implementation. This definition emphasized following aspects: (i) they are voluntary agreements; (ii) they are multi-stakeholders initiatives (iii) they aim at implementation of intergovernmental commitments; (iv) they work on issues of sustainable development; and (v) they act to implement inter-governmentally agreed sustainable development goals (Mert 2009, p. 328).

In the perspective of governance, Hodge and Greve (2007) highlights six families of meanings of partnership such as (i) institutional co-operation for joint production and risk sharing; (ii) long term infrastructural contracts; (iii) public policy networks; (iv) civil society and community development; (v) contracting-out health service; and (vi) urban renewal and downtown economic development. Ham and Koppenjan (2001, p. 598) elaborate partnership from institutional perspective as cooperation of some sort of durability between public and private actors in which they jointly develop products and services and share risks, costs, and resources which are connected with these products. This definition has three merits such as (i) it highlights cooperation of some durability and cannot only take place in short-term contracts; (ii) it underlines risk sharing as a key component and other factors to share as well; and (iii) they jointly produce some- thing (a product or a service) and, perhaps implicitly, both stand to gain from mutual effort.

Summarizing: altough partnership has gained mammoth popularity in the contemporary discourse of governance and sustainable development, the debate around the concept is far from fertile yet. It seems that it is reasonably difficult to present a straightforward definition due to its multifaceted character (Hodge 2014).

This paper perceives partnership from governance and institutional perspectives rather than language game perspective, and links the concept to local governance. Thus, partnership is 
about institutional relations between and among the various actors working at local level with the aims of sharing and caring of each other in order to plan and implement development programs and thus provide better services to the citizens. This type of partnership will contribute to eliminate the weaknesses and limits of local governance institutions and promote in building their capacity to plan and implement development projects effectively and efficiently. Such partnership must address contextual and situational factors.

\section{Local governance}

The concept of governance has gained popularity in administrative sciences and public policy literature due to its multivalency, it has the ability to link up with many other theoretical concepts (Asaduzzaman and Virtanen 2016, p. 1). It is defined as a system of government concentrating on effective and accountable institutions, democratic principles and electoral process, representation and responsible structure of government in order to ensure an open and legitimate relationship between the civil society and the state (Halfani et.al. 1994, p. 4).

Stoker (1998) has suggested five broad propositions of governance. These five propositions are: (i) governance refers to a set of institutions and actors that occupy government, private and the third sector institutions; (ii) governance identifies the blurring of boundaries and responsibilities for tackling social and economic issues; (iii) governance identifies the power dependence involved in the relationships between institutions involved in collective actions; (iv) governance is about autonomous self-governing networks of actors; and (v) governance recognizes the capacity to get things done which does not rest within the power of government to command or use its authority.

Universally, local government is vital for institutionalizing and strengthening democracy, sustainable development and good governance, and extending effective service delivery to the people (Sharpe 1970; Mackenzie 1961; Stoker 1988). Fundamental purpose of local government is to reduce the gap between state and citizen and thus bring state closer to the citizen (Ikeanyibe 2018). Local government intends to promote citizen engagement in local governance through capacity building processes: this is a requisite for service users participation and engaging citizens at various stages of development programs (Cuthill \& Fien 2005).

Local governance is specifically about local citizens or communities and it refers to the exercise of authority at local community level where most of the people inhabit. Governance is determined to what extent local citizens are involved in the structure and process i.e. making 
policy according to the needs of locality (Kauzya, 2002; Jeni 1994). Local governments act based on the needs and priorities of local citizens and builds upon cooperation to work in accordance to the needs and priorities of local communities in close partnership with various agency. Thus, local governance refers to a situation where whatever governance actor (an international NGO, a central government institution, a local government agency, or a private sector enterprise) does is planned, implemented, maintained, evaluated, and controlled with the needs, priorities, interests, participation, and well-being of the local population as the central and guiding consideration (Kauzya 2002, p.5).

\section{Partnership as a tool to promote local governance capacity building}

\section{Why local governance partnership?}

Advocates of partnership put forward series of benefits of building partnership despite of the existing potential risks. In this view, partnership is essential at least to overcome three failures that are attached to unilateral action by either governments, companies or civil society (OECD, 2006; Tulder \& Zwart 2006, Kolk et.al. 2008). These failures include (i) governance failure for governments, which limits their ability to address development problems 'top down'; (ii) market failure of companies that limits their ability to become ethically virtuous; and (iii) good intensions' failure for non-profit organizations. From the micro perspective in developing countries in particular, partnership has been considered as a vital instrument in building capacity of local governance because of the failure of centrally planned economy, bureaucratic elitism, clientelist politics, partisanship and massive corruption in development projects (Sarker 2006; Haque 2003 \& 2004; Samaratunge 2007; Asaduzzaman et. al. 2016; Blair 2000; Zafarullah 2013 $\& 2007)$.

The models NPM, Good Governance and Decentralization have not been successful in building capacity of local governance over the decades (Sarker \& Zafarullah 2019). These models are difficult to implement in developing countries because of social and cultural inertia (Sarker 2006). In addition, the decentralization initiative has promoted and empowered the upper strata of the society and central administration rather than empowered and made possible capacity building of the local governance institutions. Bureaucracy still prevails in every layers of administration in developing countries (Haque 2003 \& 2004; Ryan 2004; Smoke 2003; Olowu 2003). 
The local governance institutions of developing countries are sometimes described as contextless (Vartola et. al. 2010; Haque 1996) because of some common characteristics such as bureaucratic dominance, generalist-specialist conflicts, fragmented civil service structures, conflict between merit and equity, tension between professionalism and political patronage, a widening gap between the general populace and the administration, corruption, political instability, partisanship and problems of administrative ethics (Jamil \& Panday 2011, p. 356). In fact, despite of series of reform initiatives over the last few decades, this contextless nature severely impedes the process of capacity building of the local governance across developing world.

Partnership has been considered as a tool to build the capacity of the local governance (Gray, 198 \& 1989; Brinkerfoff 2002; Gaventa 2001). Growing inability of national government to protect individual and community rights (e.g. worker's rights, human rights, environmental justice) in a globalized world, has facilitated the issue of advocacy about partnerships. The potential benefits of partnership in this respect are: it promotes empowerment of local institutions including citizens, build trust among the various stakeholders, shares knowledge, technology and resources, provides effective and efficient services, enhances sense of ownership and all these finally contribute to build capacity of local governance and 'strengthen the possibility of effective democracy building 'from below'.

Partnership creates social, governance and institutional, and resource interactions among partners which promote in building capacity of each partners (Coaffee \& Deas 2008; Pollitt 2003; Davies 2009; Hastings 1996; Frantzeskaki et al. 2013). From the perspective of dialogue, partnership (i) builds trust between actors and develops social capital; (ii) creates channel to express ideas, concerns and problems outside official routes; (iii) offers a space to express concerns about area-specific issues. To this end, governance and institutional interactions include e.g. creating and enabling integration between departments and between different policies and institutionalizing cross sector cooperation while recognize the jurisdictional integrity or constituent bodies.

Hofman et al. (2008), Figueres and Bosi (2006) and SEEM (2006) have highlighted the contributions of multi-stakeholder partnerships (MSPs). These include: (i) MSPs create dialogue between all stakeholders and government; (ii) MSPs create representation of all stakeholders interests in policies; (iii) MSPs create more options for coordination; (iv) including actors with 
knowledge and experience about local conditions can increase the compatibility and adaptation; and (v) knowledge about political parties and the affiliation of stakeholders with different political parties can assist in creating an MSPs which will create broad support.

\section{Major benefits of partnerships, capacity building and the emergence of trust}

Farazmand (2004, pp. 82-84) has written about major benefits of partnership building and asked how partnership promotes in building capacity of governance in term providing effective and efficient services and managing local, regional and global governance challenges? These include:

(i) Partnerships promote creativity, innovation, synergy, a stronger ability to tackle big problems, participation, and responsibility;

(ii) Partnership is important because of the increasing interdependence and interconnectedness among peoples, nation-states, cultures, governments, and nongovernmental civil organizations;

(iii) Globalization and global issues have created a formidable necessity in building global partnerships for all levels of governance;

(iv) Global problems such as environmental deterioration, wars, ethnic conflicts, poverty and health crises, and migration and refugee problems, are beyond any government's capacity to solve;

(v) The global exchange of information has become very easy. Internet and other computer applications have enabled citizens around the world to communicate and share information of mutual interests and concern almost anywhere on the planet;

(vi) Learning organizations are adapting to the rapid changes of their environments by acquiring information about their surrounding environments;

(vii) Partnerships contribute to involvement, the quality of positive governance, and service delivery, administration, political support, and stability among governments, citizens, private sectors, and NGOs;

(viii) Partnerships require genuine participation, which contributes to democratic, sound governance and sustainable development for a better civilization; 
(ix) The financial-economic motives for partnership concern, for example, the limited financial capacity of governments for investments, which makes the prospects of private sector co-financing very important; and

(x) The strategic-managerial motives for partnership concerns the central issues of efficiency through the application of business-like measures of cost-effectiveness, cost-control, and other criteria used in the private sector.

The aforesaid understandings compelled that as an approach or strategy, partnership has paramount recognition in the discourse of governance and sustainable development. Local governance as one of the most vital but vulnerable units of developing countries needs partnership framework with various actors such as NGOs, civil society, private sectors and community organizations in building their capacity. Partnership provides a strong basis of democratic decision-making through sharing a wider range of knowledge by various actors where citizen gets the opportunity to participate as an active development actor rather than passive.

As a concept, capacity building has a wider connotation and highly inclined by other ideas such as partnership, participation, empowerment, trust, civil society, mutual understanding and social movement (e.g. Cuthill \& Fein 2005; Asaduzzaman et al. 2016). Eade (1997) has explained capacity building from four examples: (i) it should not create dependency; (ii) it does not mean weakening the state. It is seen as a collaborative process between government and community with each group acknowledging their roles and responsibilities; (iii) it is not a separate activity; and it is not solely concerned with financial sustainability. It is similarly important in comparison with social, environmental and political dimension of development.

Partnership promotes in building trust among the various local stakeholders. It is believed that people learn to trust one another through face-to-face interaction in associations and informal social networks; norms of trust and reciprocity 'spill over' into society at large; a capacity is created for collective action in pursuit of shared goals; citizens expect, and representatives provide, competent and responsive government (Putnam 1993, Cuthill \& Fien 2005). Trust occurs when parties holding certain favorable perceptions of each other allow this relationship to reach the expected outcomes (Wheeless \& Grotz 1977). A trusting person, group or institution, will be "freed from worry and the need to monitor the other party's behavior, 
partially or entirely" (Levi \& Stoker 2000, p. 496). Thus, the capacity of local governance enhance by building mutual trust and understanding among the development actors.

Partnership is also considered as an important technique of empowering local institutions. Under the partnership framework, all collaborative actors can share and exchange ideas, knowledge, resources, experiences and technology. Finally, all these lead to empower the local governance institutions. Swanstrom et al. (2000, p. 65) have asserted that, "non-profit sector and the government are drawn to partnerships because they complement each other: the strengths of one are the weaknesses of the other and vice versa and Governments and non-profit can accomplish more if they work together."

Summarizing: partnership is a valuable tool to drive change toward more responsible, inclusive and sustainable growth. It can help to address some of the market failures, governance gaps and trust deficits that undermine the acceleration and scaling of business engagement in sustainable development. It can also serve as a platform for convening and coordinating the diverse actions of numerous actors and for building mutually reinforcing linkages between different sectors and sustainable development goals.

\section{Potential bottlenecks of building partnership}

Albeit 'partnership' has emerged as a big policy agenda and cornerstone (Crawford 2003, Farazmand 2004) of sustainable development discourse, the process of building partnership is not smooth and easy. There are potential risks and challenges of partnership which are very much interrelated and interdependent. They also vary from context to context.

McQuaid (2010, p. 10-14) has identified several challenges of partnership. They are: (i) Conflict over goals and objectives: misunderstanding and mistrust start among the potential partners if the goals and objectives of partnership are not clear. In many cases hidden agendas may jeopardize the whole process of partnership. (ii) Resource costs: sometimes partnership building is very costly and time consuming if the partners do not agree or not willing to collaborate. (iii) Accountability: sharing equal responsibility and accountability is essential for effective partnership. But partnership may not play effective role if someone doesn't want to share risks, responsibility and accountability. (iv) Impact upon other services: each partner has its own mission and vision. But it is critical or problematic if they fail to address their mainstream objectives due to partnership. (iv) Organizational difficulties: each organization has 
its own objectives and styles of working. So this may create conflict among the partners. (v) Capacity building gap: in case of partnership building some partners might not have enough capacity to collaborate others and this might be disheartening them. (vi) Differences in philosophies among partners: this is very potential risk in building partnership because of philosophical gap. Philosophical gap is derived from social and cultural inertia. (vii) Power relations: sharing power is very difficult issue in developing countries. Especially politicians and bureaucrats are never willing to compromise with other partners such as civil society and NGOs. (viii) Community participation: superiority and inferiority complex has created a big gap between community and public institutions. Osborne (1998) has also warned against the danger of community-level actors becoming the 'puppets' of government agencies, which may be attracted to indulging in tokenistic forms of local consultation rather than less comfortable discussions with street-level groups representing the full diversity of community interests (cf. McQuaid 2010, p. 14).

To take another example, Farazmand (2004, p. 91-92) has identified a number of obstacles for partnership such as (i) distrust: according to him it is the vital obstacle to build partnership. Mutual respect and recognition is also another obstacle; (ii) the widening gap between north and south; (iii) the tendency of certain power structures to dominate other; (iv) higher expectations; (v) environmental and contextual factors; (vi) social, cultural and religious obstacles; and (viii) ethnic and racial differences.

Summing up, the major challenges for partnership building can be identified as leadership challenges, issues of power and benefit sharing, conflict of interests, role conflicts, ideological and political conflicts, misunderstanding and unwillingness.

Despite of the aforementioned bottlenecks, it is hard to deny the role of partnership as a vital strategy to meet the crisis of $21^{\text {st }}$ century. Sustainable development goals cannot be achieved without promoting and scaling private sector engagement and collective action by private, government, NGOs, community and civil society. Action by individual institution is necessary but not adequate to drive transformational and systemic change toward sustainable development. Partnership is essential at all levels and particularly at local level since majority of the population lives there. 


\section{Conclusions, discussion and future research agenda}

The evolution of partnership as practice and as a concept has indeed been a lengthy one. Academic discussions and debates are still booming around partnership and no wonder: partnership has strong explanatory power in describing and categorizing practices at the local level of governance. A genuinely adequate question is: why partnership remains strong and still not fully explored concept?

Firstly, one reason for this is that societies are becoming increasingly complex. This contradicts with theories and existing knowledge about public institutions and organizations at all levels of governance, out of which local level of governance is of key interest because it is there, where governments "meet" the citizens and service users. Complexity brings about new challenges to public policy making and managing public organizations. In this kind of setting, partnership offers theoretical, conceptual and yet very practical tool how and with whom to navigate in the planning, implementation and evaluation stages of public policy making. At best, partnership offers new cross-cutting horizons, built-in cooperation possibilities and fresh foresight perspectives to prevailing, evolving and upcoming societal problems, which challenge to policy-making at local level.

Secondly, public sector legitimacy stems from the democracy perspective, strengthening the role of democratic society by providing stability in society in the age of political turmoil, instability, changing political environment and political populism. Partnership can contribute also to this end - the democratization of society - provided that it is recognized at the local level of governance as a societal goal and as a change mechanism. Partnership does not happen by itself, since it does not exist as an autonomous phenomenon, but it requires agency to be fulfilled: somebody has to take action if something is going to take place.

Third, the idea and concept of partnership has brought about the need to re-think institutional and organizational leadership models in public sector. For instance, the mainstream leadership and management tradition which prevailed in the 1990s — the New Public Management - was to a great extent based on the idea of leading and managing single public sector organizations, whereas the New Public Governance at the beginning of 2000 focused e.g. on the networks in-between single organizations. It was the idea of partnership in particular which made possible this new conceptual as well as very practical approach and the new idea to conceive governance in a fresh way at the local level of public organizations. 
Fourth, we live in a global service society which touches upon everyday lives of billions of people globally. Approached from this perspective, partnership is relevant concept because service society penetrates public sector also from the perspective of partnership-related ecosystems and building of cooperation based on partnerships at all levels of governance - from multinational to national and from regional to local, and vice versa.

Summarizing: the concept and practice of partnership can be approached from two dimensions. First it can be conceived (i) as an ultimate societal goal or secondly (ii) as a pervasive societal mechanism.

Partnership as an ultimate societal goal refers firstly to organized cooperation based on human motivation, which has been a leading modus operandi in the history of human civilizations. The greatest inventions and innovations in the history of human civilizations have one strikingly common feature: they have taken place based on organized cooperation, which is a crucial feature in partnership. Secondly, partnership is a value adding proposition in creating societal innovations and this is because innovations are cumulative by nature and very seldom occur in isolation. This means that they have long lead-times and they result often from preexisting innovation activity: that is, partnership among human beings. Third, partnership has changed not only our understanding about leadership in public organizations, it has also changed the way we think about the traditional categories of policy instruments (legislation and regulation, resources and knowledge). The new understanding about policy instruments strongly include the idea of co-creation and deliberative democracy, which - in practice - means that citizens and service users are in a position to give voice in policy planning and implementation also at the local level of governance.

Partnership as a pervasive societal mechanism refers firstly to the variety of ways of how power is exercised in society. It can be either power over or power with to use the wording of classical organizational theorists. Partnership is also about power with which brings about new forms and mentalities about being in contact and communicating with your fellow human beings. Partnership maintains the idea that the debate replaces with dialogue as well policy planning paternalism is substituted with co-creation. Second, partnership constitutes on collective good and the betterment of society, which relates also to sustainable development of society and the role of societal innovations. This is an important conclusion because it refers also to redistribution of goods in society, which is one of the key issues in democratic society. This 
crucial question is: if we accept the fact that social betterment of society and innovations occur and take place through collective processes, should then the benefits of that process be shared collectively? And if so, how it is done?

Finally, the concept of partnership sets out number of possibilities for future research and inquiry. These include, for instance, the more detailed empirical cultivation of the role of partnership as a form of organized cooperation at various policy fields at local levels of governance in different country settings and within different public sector leadership and management traditions. Moreover, the complexities of modern society and the attached partnership configurations should be scrutinized both theoretically and empirically in more detail as well as partnership as a "business model" in public policy making to understand more how partnership links with innovations and the betterment of society. Additional important research topics are, for instance, the stability and predictability of local partnerships, the role of individual actors as gatekeepers in the networks of local levels governance, buildings blocks and milestones in the development of long-standing partnership, as well as partnership in organizational framework (cross-boundary cooperation within organizations, organizational networks and inbetween various organizations).

\section{References}

Asaduzzaman, M. and Virtaneen, P. (2016) Governance Theories and Models, in (Ed.)

Farazmand, A. Global Encyclopaedia of Public Administration, Public Policy and Governance, Springer Publication.

Asaduzzaman, M. et.al. (2016) Strengthening Local Governance in Developing Countries: Partnership as an Alternative Approach, Public Organization Review, 16(3): 335-356.

Austin, J. (2000) The Collaborative Challenge, San Francisco: Jossey-Bass.

Birner R and Wittmer H. (2006) Better Public Sector Governance through Partnership with the Private Sector and Civil Society: The case of Guatemala's Forest Administration, International Review of Administrative Sciences, 72(4):459-472.

Blair H. (2000) Participation and Accountability at the Periphery: Democratic Local Governance in Six Countries, World Development, 28(1): 21-39.

Boydell, L. (2007) Partnerships: A Literature Review, Dublin: Institute of Public Health in Ireland 
Brinkerhoff, J.M. (2002) Government-Nonprofit Partnership: A Defining Framework, Public Administration and Development, 22:19-30.

Coaffee, J., and Deas, I. (2008) The Search of Policy Innovation in Urban Governance: Lessens from Community Lead Regeneration Partnerships, Pub. Pol. Admin, 23(2):167-187.

Cuthill, M. and Fien, J. (2005) Capacity building: Facilitating citizen participation in local governance, Australian Journal of Public Administration, 64(4):63-80.

Davies, J.S. (2009) The Limits of Joined-up-Government: Towards a Political Analysis, Public Administration, 87(1):80-96.

Eade, D. (1997) Capacity-Building: An Approach to People-centered Development Oxfam Publication, London.

Farazmand, A. (2004) Building Partnerships for Sound Governance, in (edi.) Farazmand, A., Sound Governance: Policy and Administration Innovation, Prager, pp. 77-111.

Farazmand, A. (1999). Building Partnerships for Governance. Background paper presented at the UN-sponsored World Congress on Governance, Manila, the Philippines, May 31June 4.

Farazmand, A. (1998), "Privatisation or reform? Public enterprise management in transition", International Review of Administrative Sciences, Vol. 65 No. 4, pp. 551-67.

Figueres, C. and and Bosi, M. (2006) Achieving Greenhouse Gas Emission Reductions in Developing Countries Through Energy efficient Lighting Projects in the Clean Development Mechanism, World Bank, Washington.

Frantzeskaki, N. et al. (2013) The Role of Partnerships in 'Realising' Urban Sustainability in Rotterdam's City Ports Areas, The Netherlands, Journal of Cleaner Production, xxx:112.

Gaventa, J 2001 Towards Participatory Local Governance: Six Propositions for Discussion. Institute of Development Studies, University of Sussex. www.ids.uk.ac.

Gray, B. (1989) Collaborating, San Francisco: Jossey-Bass.

Crawford, G. (2003) Partnership or power? Deconstructing the 'Partnership for Governance Reform' in Indonesia, Third World Quarterly, Vol 24, No 1, pp 139-159

Ham, V.H. and Koppenjan, J. (2001) Building Public-Private Partnerships: Managing and Assessing Risks in Port Development, Public Management Review, 3(4):593-616.

Haque, M.S (2004) Governance Based on Partnership with NGOs: Implications for 
Development and Empowerment in Rural Bangladesh, International Review of Administrative Sciences, 72(2): 271-290.

Haque M.S. (2003) Reinventing Governance for Performance in South Asia: Impact on Citizenship Rights, International Journal of Public Administration, 26 (8 \& 9): 1-23.

Haque, M.S. (2007) Theory and Practice of Public Administration in Southeast Asia: Traditions, Directions, and Impacts, Intl Journal of Public Administration, 30: 1297-1326, 2007.

Haque, M.S (1996) The Contextless nature of public administration in Third World countries, International Review of Administrative Sciences, 62:315-329

Hastings, A. (1996) Unraveling the Process of Partnership in Urban Regeneration Policy, Urban Studies, 33 (2):253-268

Hodge, G.A. and Greve, C. (2009) PPP: The Passage of Time Permits-A Sober Reflection, Economic Affairs, 29(1):33-39.

Hodge, G.A. (2014) Rethinking Public Private Partnership: Global Retrospect and Bangladesh Prospect, in (Edi.) Ahmed, N. (2014), 40 Years of Public Administration and Governance in Bangladesh, University Press Limited, Dhaka

Hodge, G.A. and Greve, C. (2007) Public-Private Partnerships: An International Performance Review, Public Administration Review, 67(3): 545-558.

Hofman, P.S. et al. (2008) Making Global Technology Works for Combating Climate Change and Contribution to MDGs, Dutch Foreign Ministry, University of Twente.

Hughes, O.E. (1998), Public Management and Administration, Macmillan, London

Minogue, M. (1998), "Changing the state: concepts and practice in the reform of the public sector", in Minogue, M., Polidano, C. and Hulme, D. (Eds), Beyond the New Public Management, Edward Elgar, Cheltenham, pp. 17-37.

Nelson, J. (nd) Partnerships for Sustainable Development: Collective Action by Business, Governments and Civil Society to Achieve Scale and Transform Markets, Business and Sustainable Development Commission, Harvard Kennedy School, available at: https://www.hks.harvard.edu/sites/default/files/centers/mrcbg/programs/cri/files/PforSD(Exec _Summary).pdf

Jamil, I., \& Pranab, P. (2011). Inter-organizational coordination and corruption in urban policy implementation in Bangladesh: a case of Rajshahi City corporation. International Journal of Public Administration, 35:352-366. 
Jeni, K. (1994) "Decentralization: A Survey of Literature from a Human Development

Perspective," Human Development Occasional Papers (1992-2007) HDOCPA-1994-05, Human Development Report Office (HDRO), United Nations Development Programme (UNDP).

Kauzya, J-M. (2002) 'Local Governance Capacity Building for Full Range Participation:

Concepts, Frameworks, and Experiences in African Countries', 4 th Global Forum on ReInventing Government, New York, United Nations, pp. 361-362, available at: http://unpan1.un.org/intradoc/groups/public/documents/UN/UNPAN005783.pdf

Kolk, A. et.al. (2008) Business and Partnership for Development, European Management Journal, 26: 262-273.

Mackenzie W.T.M. (1961) Theories of Local Government, London, UK: Greater London Capers.

McQuaid, R.W. (2000) “The Theory of Partnerships - Why have Partnerships", in: S.P. Osborne (ed.), Managing public-private partnerships for public services: an international perspective (Routledge, London) pp. 9-35.

Mert, A. (2009) Partnership for Sustainable Development as Discursive Practice: Shifts in Discourses of Environment and Democracy, Forest Policy and Economics, 11:326-339.

OECD (2006) Evaluating the Effectiveness and the Efficiency of Partnerships, Workshop on Evaluating the Effectiveness and Efficiency of Partnerships, Paris, OECD Environment Directorate.

Olowu, D. (2003). Challenge of multi-level governance in developing countries and possible GIS applications. Habitat International, 27, 501-522.

Osborne, S. (1998) Partnerships in local economic development: a bridge too far for the voluntary sector? Local Economy 12 (4): 290-295.

Pollitt, C. (2003) Joined Up Governance: A Survey, Polit. Stud. Rev. 1(1):34-49.

Putnam, R. (1993) Making Democracy Work: Civic Traditions in Modern Italy, Princeton University Press.

Ryan, J. J. (2004). Decentralization and democratic instability: the case of Costa Rica. Public Administration Review, 64(1), 81-91.

Samaratunge, R., et al. (2008). The new public management reform in Asia: a comparison of 
Southeast Asian Countries, International Review of Administrative Sciences, 74(1), 2546.

Sarker, A.E. (2008) Patron-Client Politics and Its Implications for Good Governance in Bangladesh, International Journal of Public Administration, 31(12):1416-1440.

Sarker, A.E and Zafarullah, H.M. (2019) Political Settlements and Bureaucratic Reforms: An Exploratory Analysis Focusing on Bangladesh, Journal of Asian and African Studies, 119

Sarker, A.E. (2006) New public management in developing countries: An analysis of success and failure with particular reference to Singapore and Bangladesh, International Journal of Public Sector Management, 19(2):180-203.

SEEM (2006) Market Transformation to Promote Efficient Motor Systems, Project launch Paper, Standards for Energy Efficiency of Electric Motor Systems (SEEM), Zurich.

Selsky, J.W. and Parker, B. (2005) Cross-Sector Partnerships to Address Social Issues: Challenges to Theory and Practice, Journal of Management, 31(6):849-873).

Sharpe L.P. (1970) Theories and values of local government. Political Studies 18(2): 153-174.

Smoke, P. (2003). Decentralization in Africa: goals, dimensions, myths and challenges. Public Administration and Development, 23, 7-16.

Stoker G (1988) The Politics of Local Government London, UK: Macmillan, Stoker G (1998) Governance as theory: five propositions. International Social Science Journal, 50(155): $17-28$.

Stone, M. (2000) Exploring the Effects of Collaborations on Member Organizations: Washington Country's Welfare-to Work Partnership, Non-Profit and Voluntary Sector Quarterly, 29(1):98-119.

Swanstrom, et al. (2000). Rethinking the Partnership Model of Government -Non-profit Relations, in Richard C. H. et al. Non-profits in Urban America, Quorum Greenwood, p.65.

Tulder, V.R., and Zwart, V.A. (2006) International Business Society Management: Linking Corporate Responsibility and Globalization, Rutledge

Wheeless, L.R. and Grotz J. (1977) The Measurement of Trust and Its Relationship to SelfDisclosure, Human Communication Research, 3(3): 250-257.

World Bank Group (2014) Public-Private Partnership: Reference Guide, Version 2.0, 
available:http://documents.worldbank.org/curated/en/600511468336720455/pdf/903840P PP0Refe0Box385311B000PUBLIC0.pdf

Young, D.R. (1999) Alternative Models of Government-nonprofit Sector Relations: Theoretical and International Perspectives, Non-Profit and Voluntary Sector Quarterly, 29(1):149172.

Zafarullah, H. and Huque, A.S. (2012) Managing Development in a Globalized World: Concept, Process and Institutions (Boca Raton, FL:CRC Press?Taylor \& Francis).

Zafarullah, H. (2007) Bureaucratic elitism in Bangladesh: The pre-dominance of generalist administrators, Asian Journal of Political Science 15(2): 161-173.

Zafarullah, H. (2013) Bureaucratic culture and the social-political connection: The Bangladesh example, International Journal of Public Administration 36(13): 932-939. 